\title{
Mitochondrial DNA synthesis studied autoradiographically in various cell types in vivo
}

H. Korr, C. Kurz, T.O. Seidler,

D. Sommer and C. Schmitz

\author{
Department of Anatomy and Cell Biology, \\ RWTH University of Aachen, Aachen, Germany
}

\section{Correspondence \\ H. Korr \\ Department of Anatomy and \\ Cell Biology, Faculty of Medicine \\ RWTH University of Aachen \\ Wendlingweg 2 \\ D-52057 Aachen \\ Germany \\ Fax: +49 $2418888-431$ \\ E-mail: korr@alpha.imib.rwth- \\ aachen.de}

Presented at the 5 th International Symposium on Radioautography,

São Paulo, SP, Brasil,

August 24-26, 1997

Research supported by the Deutsche Forschungsgemeinschaft

(Nos. Ko 715/2-1 and 3-1).

Received August 15, 1997 Accepted September 18, 1997

\section{Abstract}

It is generally accepted that mitochondria are able to proliferate even in postmitotic cells due to their natural turnover and also to satisfy increased cell energy requirements. However, no detailed studies are available, particularly with respect to specific cell types. Since $\left[{ }^{3} \mathrm{H}\right]-$ thymidine is incorporated not only into nuclear (n) DNA but also into the DNA of cytoplasmic mitochondria, an autoradiographic approach was developed at the light microscopy level in order to study basic questions of mitochondrial (mt) proliferation in organs of rodents in situ via the cytoplasmic incorporation of $\left[{ }^{3} \mathrm{H}\right]$-thymidine injected into the animals $1 \mathrm{~h}$ before sacrifice. Experiments carried out on mice after $\mathrm{X}$-irradiation showed that cytoplasmic labeling was not due to a process such as unscheduled nuclear DNA synthesis (nUDS). Furthermore, half-lives of mitochondria between 8-23 days were deduced specifically in relation to cell types. The phase of mtDNA synthesis was about $75 \mathrm{~min}$. Finally, mt proliferation was measured in brain cells of mice as a function of age. While all neurons showed a decreasing extent of mtDNA synthesis during old age, nUDS decreased only in distinct cell types of the cortex and hippocampus. We conclude that the leading theories explaining the phenomenon of aging are closely related, i.e., aging is due to a decreasing capacity of nDNA repair, which leads to unrepaired nDNA damage, or to an accumulation of mitochondria with damaged mtDNA, which leads to a deficit of cellular energy production.

\section{Introduction}

Mitochondria, which generate energy for cellular processes through oxidative phosphorylation, contain their own DNA in contrast to other organelles with the exception of the nucleus. This mitochondrial (mt) DNA differs from nuclear (n) DNA (1). The observation that persistent damage to mtDNA is correlated with distinct human diseases (for a review, see Ref. 2, among others) has stim-
Key words

- Aging

- Autoradiography

- Mitochondrial DNA synthesis

- Turnover of mitochondria

- Unscheduled DNA synthesis ulated research concerning mtDNA. General information about mtDNA synthesis has been available for many years (first important review, Ref. 3). However, many questions concerning details remained unanswered, particularly those related to specific cell types within an organ. This may be due to the fact that mostly biochemical or - more recently molecular biology techniques were used which depend on isolated mtDNA from larger pieces of tissue. However, mtDNA like 
Figure 1 - Scheme of DNA excision repair. The rope ladder represents the DNA double helix. After X-irradiation, but also sporadically, single strand breaks occur. A few steps of this repair are shown. Around the point of fracture, a few bases are snipped out which will be newly synthesized and inserted into the DNA strand (dots). If $\left[{ }^{3} \mathrm{H}\right]$-thymidine $\left(\left[{ }^{3} \mathrm{H}\right]-\mathrm{TdR}\right)$ is applied, DNA repair synthesis (unscheduled nuclear DNA synthesis) can be shown autoradiographically.

Figure 2 - Autoradiographs of Feulgen-prestained and light green-poststained paraffin sections showing comparable parts of the cortex $1 \mathrm{~h}$ after $\left[{ }^{3} \mathrm{H}\right]-\mathrm{TdR}$ injection of a 6-month-old mouse (a), or of a control mouse which received no $\left[{ }^{3} \mathrm{H}\right]-\mathrm{TdR}(\mathrm{b})$. The two autoradiographs were processed under identical conditions and exposed for 250 days. Bar, $10 \mu \mathrm{m}$.
nDNA can be labeled specifically with $\left[{ }^{3} \mathrm{H}\right]-$ thymidine (TdR) (4-6). This permitted the study of mitochondria within tissue cells using electron microscopic autoradiography (EM ARG) which up to now - in addition to cells in culture - had been applied mostly to rat adrenal glands (7-11). In order to answer questions related to the kinetics of $\mathrm{mt}$ reduplication within different cell types of an organ, EM ARG studies are much too tedious. Light microscopic (LM) autoradiographic studies would be more desirable, but
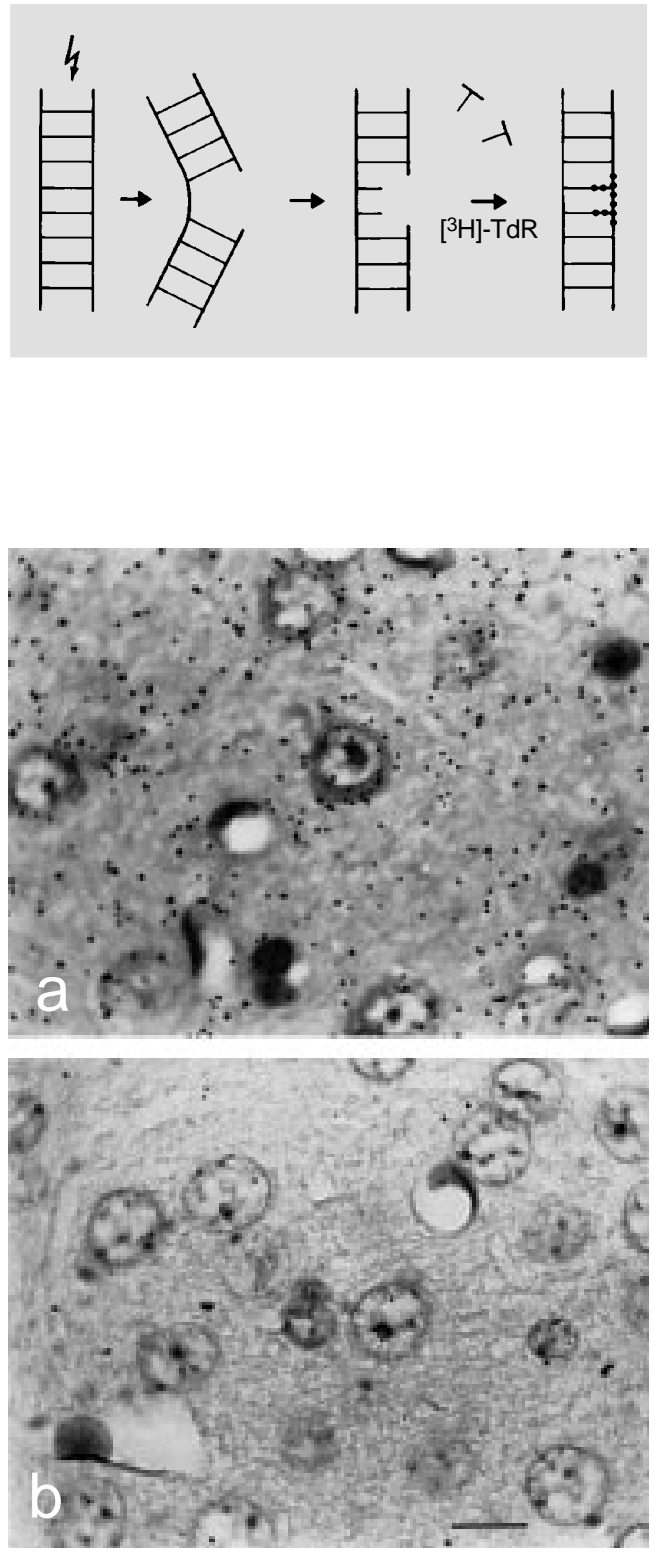

an LM autoradiograph prepared after $\left[{ }^{3} \mathrm{H}\right]-$ TdR application and exposed only for a few days as done for the study of cell proliferation, i.e., labeling of the nucleus, will not show any mt labeling within the cytoplasm; this is due to the fact that the DNA content of all mitochondria in a cell is only about $0.15 \%$ of the DNA content of the cell nucleus (3).

However, a breakthrough came from LM autoradiographic studies of unscheduled nuclear DNA synthesis (nUDS) in various cell types of the mouse brain $(12,13)$, where - particularly without pretreatment of the animals - only a very small amount of $\left[{ }^{3} \mathrm{H}\right]$ $\mathrm{TdR}$ is incorporated into the nucleus (Figure 1). A very long exposure time of several months was used for the demonstration of nUDS due to the general autoradiographic rule that grains per structure correspond to the product of radioactivity present in the structure times exposure time (provided that the autoradiographic emulsion used works linearly with increasing time). Using such a long exposure time, mtDNA synthesis was demonstrable by light microscopy in the perikaryal cytoplasm of some types of neurons (Figure 2a). In our experiments on mice, killed $1 \mathrm{~h}$ after injection of $\left[{ }^{3} \mathrm{H}\right]-\mathrm{TdR}$, exposure time was 250 days or about 9 months. This marked the beginning of new experiments in order to elucidate the life history of mitochondria in more detail. Since results regarding mtDNA synthesis were obtained from experiments in which nUDS was also measured, distinct results related to nUDS will also be reported in this article.

\section{Prerequisites for analyzing and interpreting mtDNA synthesis}

\section{Incorporation of radioactively labeled thymidine into nDNA and mtDNA}

From the first experiments of Reichard and Estborn (14) up to now, it is unquestioned that TdR is a specific precursor of nDNA as well as mtDNA (for a review, see 
Ref. 15, among others). However, when using autoradiographic exposure over a period of many months, thus, reaching a high sensitivity, the specificity of the labeling should be re-evaluated. This means that the question of how far the grains still represent $\left[{ }^{3} \mathrm{H}\right]$ DNA (plus background, see below) should be answered. We should mention as a first argument for the specificity of the labeling that all autoradiographs were prepared from Feulgen-prestained sections. This mode of pretreatment leads to a loss of all acid-soluble substances. Furthermore, we tested on adult mice whether an injection of $\left[{ }^{3} \mathrm{H}\right]$-water, the main degradation product of $\left[{ }^{3} \mathrm{H}\right]-\mathrm{TdR}$ in vivo (16), leads to labeling above background. The evaluations showed that only in the case of large neurons (cortical and hippocampal pyramidal cells, Purkinje cells) did a small but significant labeling occur which was about $15-20 \%$ of that observed $1 \mathrm{~h}$ after $\left[{ }^{3} \mathrm{H}\right]-\mathrm{TdR}$ injection (17). Smaller neurons (hippocampal and cerebellar granular cells), glial cells and cells of organs outside the brain (kidney epithelial cells of the proximal tubule, hepatocytes and skeletal muscle cells) showed no labeling $1 \mathrm{~h}$ after injection of $\left[{ }^{3} \mathrm{H}\right]$-water. Thus, based on these results (which are in accordance with the literature $(18,19))$, it is reasonable to conclude that after considering background labeling - most of the grains observed after $\left[{ }^{3} \mathrm{H}\right]-\mathrm{TdR}$ administration represent $\left[{ }^{3} \mathrm{H}\right]$-DNA. Background labeling, however, was determined specifically for each cell type from autoradiographs obtained from mice not injected with $\left[{ }^{3} \mathrm{H}\right]-\mathrm{TdR}$ or $\left[{ }^{3} \mathrm{H}\right]$-water and exposed under completely identical conditions as those the background of which should be determined (Figure 2b). Background correction was carried out according to the procedure described by Korr and Schmidt (20), i.e., considering Poisson probabilities (21).

\section{Interpretation of $\left[{ }^{3} \mathrm{H}\right]-\mathrm{nDNA}$}

Since the pioneering experiments of
Howard and Pelc (22) there is no doubt that DNA synthesis - if large amounts of DNA are newly synthesized - takes place only during a specific time period prior to mitosis. Thus, nuclear labeling with $\left[{ }^{3} \mathrm{H}\right]-$ or $\left[{ }^{14} \mathrm{C}\right]-$ $\mathrm{TdR}$ (or with bromodeoxyuridine visualized immunocytochemically; for a review, see Ref. 23) indicates cell proliferation, if the rare event of polyploidization is disregarded (see 24). From 1964 onwards (25-27), evidence accumulated that, in addition to cell proliferation, DNA synthesis to a very small extent also occurs in the course of DNA excision repair. However, both types of labeling can be clearly separated due to the fact that the mean grain numbers per nucleus are extremely different (by a factor of about 6,000; Ref. 28). DNA synthesis in the course of DNA excision repair is shown schematically in Figure 1. When repairing DNA strand breaks produced by free radicals (e.g., by Xirradiation, but also spontaneously, mainly in the course of mitochondrial energy production) only about 1-4 nucleotides per break will be excised and subsequently newly synthesized and inserted. This number increases to about 80-100 nucleotides if a dimer arises (e.g., by UV irradiation or distinct chemical substances; 29,30). Our extensive studies on different cell types within many organs of untreated rats and mice carried out during the last 15 years have shown that spontaneous nUDS occurs continuously in all nucleated cells. However, the extent of nUDS differs considerably among different cell types $(13,31)$.

\section{Interpretation of $\left[{ }^{3} \mathrm{H}\right]-\mathrm{mtDNA}$}

As discussed above, cytoplasmic labeling after $\left[{ }^{3} \mathrm{H}\right]-\mathrm{TdR}$ injection mainly represents $\left[{ }^{3} \mathrm{H}\right]-D N A$. Since the only organelles outside the nucleus of a mammalian cell that contain DNA are the mitochondria, it is evident from a theoretical point of view that cytoplasmic $\left[{ }^{3} \mathrm{H}\right]$-DNA belongs to mitochondria. This was explicitly shown with EM 
ARG for cells cultured in vitro by many authors in the past. Recently, in addition to the in vivo studies mentioned above, $\left[{ }^{3} \mathrm{H}\right]-$ labeled mitochondria were observed within perikaryal cytoplasm, but also within axons and dendrites of rat facial motoneurons during regeneration 4 days after axotomy, i.e., a period with a remarkably increased extent of mtDNA synthesis (32). Taken together, it is evident that the cytoplasmic labeling observed in long-exposed LM autoradiographs (Figure 2) occurs in mitochondria.

In order to interpret the labeling of mtDNA with $\left[{ }^{3} \mathrm{H}\right]-\mathrm{TdR}$ correctly, the question should be answered whether or not a process like nUDS also exists for mtDNA. Since it is known that strand breaks occur after X-irradiation within nDNA (33-37) as well as within mtDNA (38), nUDS and mtDNA synthesis were studied in brain cells of adult mice as a function of X-ray dose. For details of the experiments and results regarding nUDS, see Korr et al. (13). Briefly, the mice received $\left[{ }^{3} \mathrm{H}\right]-\mathrm{TdR}$ and were immobilized by being inserted into perforated plastic tubes. The heads of the mice were $\mathrm{X}$ irradiated (7 Gy/min) 2 min after $\left[{ }^{3} \mathrm{H}\right]-\mathrm{TdR}$ injection with a dose of up to $100 \mathrm{~Gy}$. The

Figure 3 - Mean grain densities including standard error of the means (SEM; corrected for background and $\left[{ }^{3} \mathrm{H}\right]-\beta$-absorption) for the perikaryal cytoplasm of various cell types in the brain of the adult mouse after $\left[{ }^{3} \mathrm{H}\right]-\mathrm{TdR}$ injection plus 2-100 Gy X-irradiation of the head (hatched bars) or $\left[{ }^{3} \mathrm{H}\right]-\mathrm{TdR}$ injection and shamirradiation (open bars).

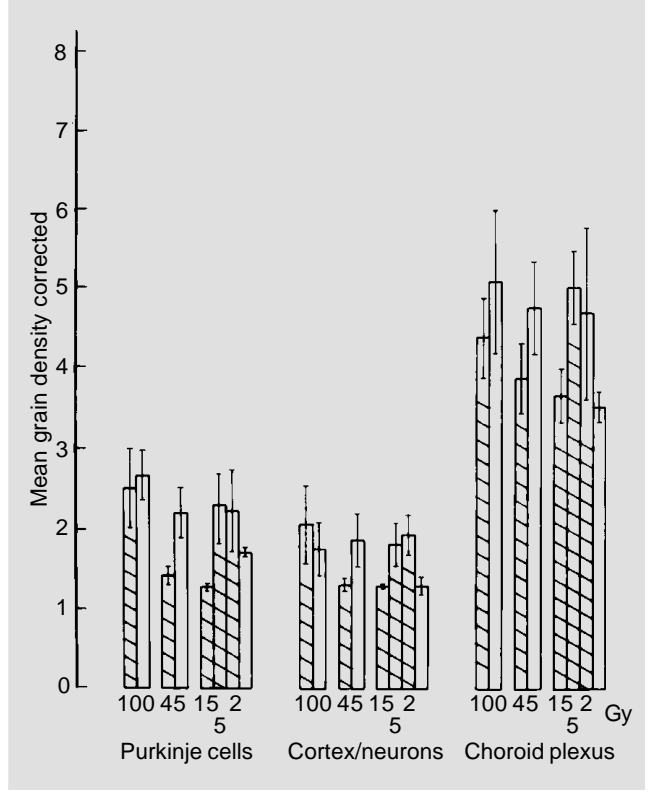

animals were killed $1 \mathrm{~h}$ after $\left[{ }^{3} \mathrm{H}\right]-\mathrm{TdR}$ injection. While nUDS of all cell types studied increased linearly with increasing dose (this increase was again quite different among the cell types and reflected their radiosensitivity), the extent of mtDNA synthesis remained unchanged (Figure 3). This indicates, in accordance with previous biochemical studies $(39,40)$, that mtDNA breaks will not be repaired by a mechanism by which mtDNA is newly synthesized at a level that is still measurable. The question of how far mtDNA damage can be repaired at all is presently under discussion (41).

For further interpretation of $\left[{ }^{3} \mathrm{H}\right]-\mathrm{mtDNA}$ it should be considered that the mtDNA content per mitochondrion of mammalian cells is constant; however, the number of mitochondria per cell differs among the various cell types (42). In the case of specific cell lines obtained from cancer cells, but also in the slime mold Physarum polycephalum during differentiation, the number of mtDNA molecules per cell increases considerably due to endoduplication $(43,44)$. Nevertheless, as is the case for polyploidization of nDNA (see above), endoduplication also seems not to be a normal event within the life cycle of mitochondria belonging to a cell of an untreated rat or mouse. Thus, it is reasonable to assume that $\left[{ }^{3} \mathrm{H}\right]$-labeling of mtDNA is connected with mtDNA replication in the context of mt division and therefore with multiplication of mitochondria. It is evident that mitochondria multiply in the course of cell division (for a review, see Ref. 45). However, postmitotic cells also show multiplication of mitochondria, a fact that was decisively demonstrated in cells of the adrenal fasciculate zone of adult rats showing a replacement of regenerating mitochondria with a half-life of about 11 days (10). Furthermore, increased mtDNA synthesis was observed in various postmitotic cells after hormonal treatment, acute exercise (reviewed by Ashwell and Work, 46), and facial nerve axotomy (32). These examples support the 
conclusion that a temporarily increased need for cellular energy induces acute multiplication of mitochondria.

\section{Quantifications}

If the extent of nUDS or mtDNA synthesis is to be compared among different cell types in autoradiographic studies after $\left[{ }^{3} \mathrm{H}\right]$ TdR injection, the grain numbers per nucleus or cytoplasmic grain densities must be corrected because the grains do not really represent the radioactivity incorporated into the section volume of the cell structure of interest. This is due to the fact that $\left[{ }^{3} \mathrm{H}\right]-\beta$-particles have a very low energy and thus not all $\beta$-particles reach the emulsion layer. Figure 4 illustrates this specific problem schematically. As clearly shown by Maurer and Primbsch (47), mass density of the cellular structure is the relevant factor leading to the so-called $\left[{ }^{3} \mathrm{H}\right]-\beta$-self-absorption correction factors. Only after consideration of these factors, which are specific in relation to cell type and age of the animal, can the grain numbers or densities be compared among different cell types. A compilation of correction factors is given by Korr (48) and Korr et al. (49), mainly for cell types of the brain of mice of different ages.

If the grain numbers per nucleus of nuclei of different size but with the same level of ploidy are compared in studies of nUDS (e.g., cortical pyramidal cells vs cerebellar granular cells), the relative DNA content within the nuclear volume in the section must be considered, since an increased nuclear size leads to a decreased mean relative DNA content within the volume. A stereological-based methodology was developed which leads to corresponding so-called normalization factors (50).

\section{Turnover of mitochondria}

According to biochemical studies using whole brains, the half-life of mitochondria in the brain of adult rats is about 31 days (51). In order to answer the question whether this half-life is equal for all cell types in the brain, a group of adult mice received a single injection of $\left[{ }^{3} \mathrm{H}\right]-\mathrm{TdR}\left(1.11 \mathrm{MBq}\left[{ }^{3} \mathrm{H}\right]-\mathrm{TdR} /\right.$ $\mathrm{g}$, intraperitoneally (ip)). Three mice each were killed $1 \mathrm{~h}$, and 1,2,7, and 30 days later. In addition, one mouse, which received no $\left[{ }^{3} \mathrm{H}\right]-\mathrm{TdR}$, was used to measure background labeling with respect to the specific cell type. After Feulgen prestaining and light green poststaining, autoradiographs were prepared from 3- $\mu \mathrm{m}$ thick deparaffinized sagittal sections (Ilford K-2; 250-day exposure). Figure 5 shows typical results obtained for nUDS and mtDNA synthesis of cortical pyramidal cells. Both measurements led to a significant $(\mathrm{P}<0.05)$ increase in mean grain number per

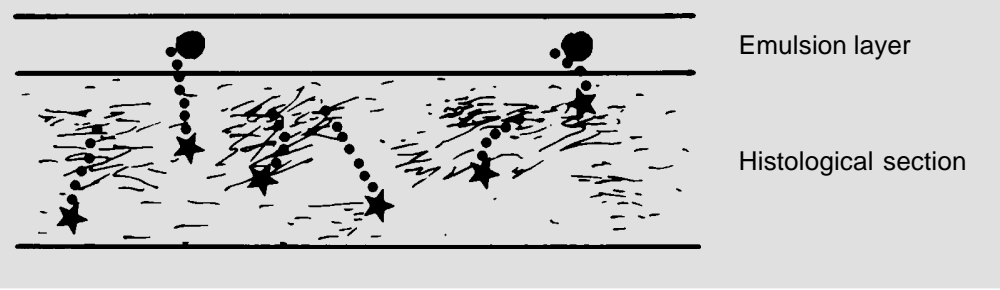

Figure 4 - Schematic illustration of an autoradiograph for demonstrating $\left[{ }^{3} \mathrm{H}\right]$ - $\mathrm{B}$-self-absorption. The stars represent decaying $B$-isotopes, and the dots virtual $B$-tracks.

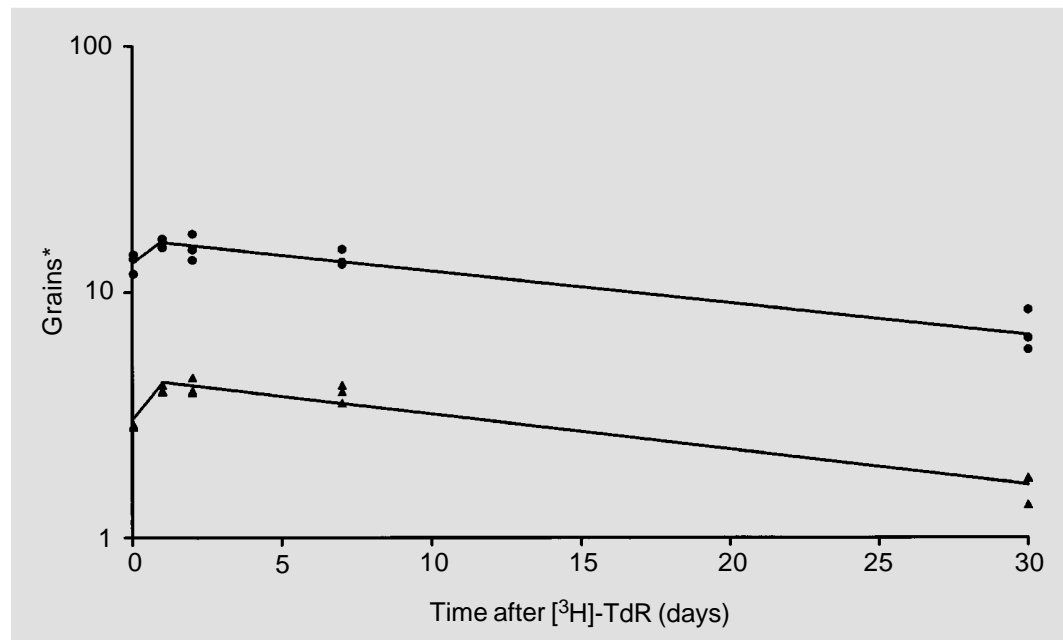

Figure 5 - Grains*, i.e., mean grain numbers per nucleus corrected and normalized (see text; circles) or corrected mean cytoplasmic grain densities (triangles) of cortical pyramidal cells, as a function of time after a single injection of $\left[{ }^{3} \mathrm{H}\right]-\mathrm{TdR}$ at $\mathrm{t}=0$ days. The lines indicate regression lines calculated for intervals with highest correlation coefficients. 
Table 1 - Half-lives of mitochondria within different cell types of the brain (I) and some body organs (II). M10, Ten months; $4 \mathrm{n}$, tetraploid.

I. Brain (adult mouse/M10)

Cell type

Half-life (days)

Mitral cells (olfactory bulb)

23.2

Cortical pyramidal cells

Hippocampal pyramidal cells CA3

21.5

Hippocampal pyramidal cells CA1/2

Cerebellar Purkinje cells

Neurons of pontic nuclei

Large neurons (medulla oblongata)

Epithelial cells (choroid plexus, VIV)

II. Organs (adult mouse/M10)

Cell type

Half-life (days)

Liver, hepatocytes (perivenous, $4 \mathrm{n}$ )

Kidney, proximal tubule

Kidney, distal tubule

8.4

15.1

Kidney, medullary collecting duct

13.1

17.7

Skeletal muscle, myocytes

Testes, Leydig cells

17.7

15.8

Prostate, epithelial cells

12.0

Seminal vesicle, epithelial cells

nucleus or cytoplasmic grain density up to 1 day, followed by a significant decrease up to 30 days after pulse labeling. Generally, similar regression lines were found for other cell types of the brain as well. However, it should be mentioned that no initial increase, but only a decreasing regression line, was seen for cells outside the brain (with the exception of skeletal muscle cells).

Based on the results presented in Figure 5 , the following conclusions can be drawn: i) Since nDNA will be damaged continuously, as mentioned above, the increase of nuclear labeling marks the accumulation of repaired DNA with increasing time. However, this increase can only be shown if $\left[{ }^{3} \mathrm{H}\right]-\mathrm{TdR}$ is available for about 1 day, i.e., much longer than the 40-60 min known from the labeling of $\mathrm{S}$ phase cells in the rodent brain (52). This longer availability might be related to the fact that only 1-4 nucleotides will be newly synthesized for repairing a DNA strand break (see above). ii) With regard to the increase of cytoplasmic labeling, it was surprising that about $80 \%$ of maximum grain density was

achieved already $1 \mathrm{~h}$ after $\left[{ }^{3} \mathrm{H}\right]-\mathrm{TdR}$ injection in all 8 neuronal cell types studied. Thus, a time interval of $74.3 \pm 2.8 \mathrm{~min}$ (mean \pm SEM) was considered to be sufficient to obtain maximum grain density. Provided that the replication of mtDNA is similar to that of nDNA, this time interval of about $75 \mathrm{~min}$ might represent the duration of the mtDNA synthesis phase; this value is in full agreement with that of about 60 min obtained for replication of mitochondria of mouse L cells in vitro (45). iii) A decrease in radioactivity, as seen for grain density in Figure 5, was also found with biochemical methods in isolated $\left[{ }^{3} \mathrm{H}\right]$-mtDNA from whole organs, and this decrease was interpreted as turnover of mitochondria from which $\mathrm{mt}$ half-lives were derived (9-11). Mt half-lives for specific cell types were calculated (Table 1) from such decreasing regression lines (Figure 5). Most neurons showed similar values from 19 to 23 days. However, the mt half-life of plexus epithelial cells was much shorter. This might be related to the high metabolic activity of these cells. Mt half-lives of cells of body organs are generally shorter than those of neurons. This agrees with biochemically determined half-lives reported in the literature (myocardiocytes: 6.7 days; liver cells: 9.4 days; kidney cells: 10.4 days; brain cells: 31 days; Ref. 51). It should be added that a similarly high mt half-life was found for rat brain cells ( 24.4 days) on the basis of $\mathrm{mt}$ protein turnover after labeling with $\left[{ }^{3} \mathrm{H}\right]-$ leucine (53).

\section{mtDNA synthesis as a function of animal age}

According to a leading hypothesis of Miquel $(54,55)$, aging is mainly caused by accumulation of damage within the mtDNA of irreversibly differentiated cells such as neurons. This persisting mtDNA damage will lead to decreasing $\mathrm{mt}$ reproduction and thus, a decreasing number of functional organelles resulting in declining ATP production. This last 


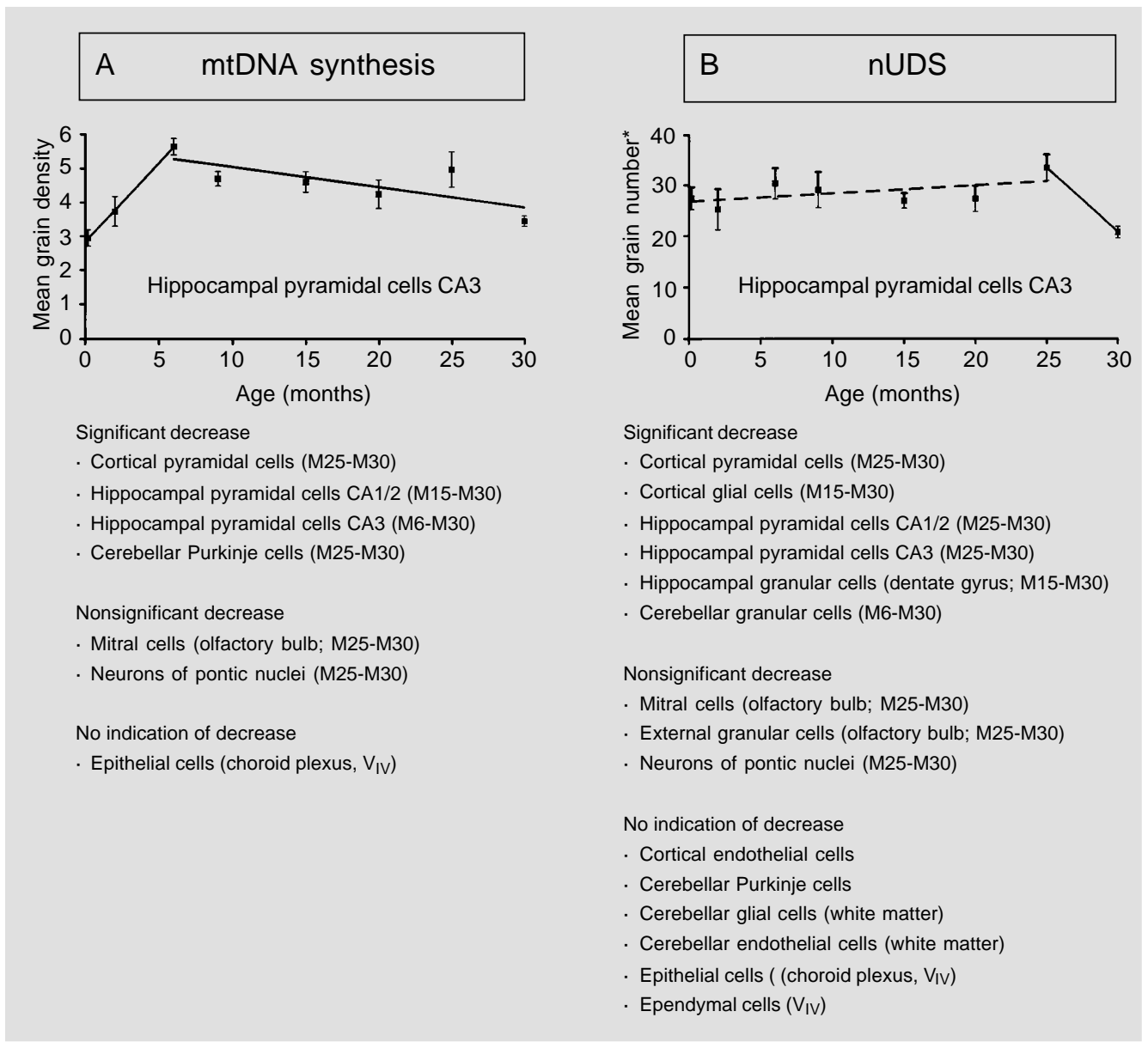

consequence is accompanied by cellular malfunctions finally leading to cell death. However, there exists another well-accepted hypothesis presented by Gensler and Bernstein (56) according to which an accumulation of unrepaired DNA damage within the nucleus (due to a decreased DNA repair capacity) is mainly responsible for the phenomenon of aging. Up to now, experiments carried out to obtain arguments pro or contra were mainly focused only on one of the two hypotheses; furthermore, biochemical studies are preferentially conducted on parts of an organ or cells in culture. However, with the use of the autoradiographic method to measure nUDS together with mtDNA synthesis, as described above, it seems to be possible to test both hypotheses specifically with respect to various cell types in the mouse brain in vivo.
The following experiment was carried out. A cohort of male Han:NMRI mice were kept under specific pathogen-free conditions which resulted in a mean life-span of 22 months. Thus, according to the American Age Association, each animal which is older than 22 months can be considered as an aged animal (57). Four mice each received ip a single injection of $1.11 \mathrm{MBq}\left[{ }^{3} \mathrm{H}\right]-\mathrm{TdR} / \mathrm{g}$ body weight at embryonic (E) day 18, postnatal (P) day 1, P5, or at the age of 2, 6, 9, 15, 20,25 , or 30 months (M2, etc.), and were killed $1 \mathrm{~h}$ later. Figure 6A and B summarizes the results, which were obtained from autoradiographs prepared from $3-\mu \mathrm{m}$ thick paraffin sections after Feulgen prestaining and light green poststaining; the exposure time was 250 days (Ilford K-2). Regression lines were drawn only for intervals with the high-
Figure 6 - Compilation of results concerning mtDNA synthesis (A) and unscheduled nuclear DNA synthesis (nUDS) (B) as a function of age of male NMR mice. $A$, Mean grain densities \pm SEM of the cytoplasm corrected for background and $\left[{ }^{3} \mathrm{H}\right]-\beta$-selfabsorption. $B$, Mean grain numbers per nucleus* \pm SEM, i.e., corrected and normalized with respect to relative DNA content (see text). Full lines represent regression lines with a slope significantly different from zero $(P<0.05$; broken line, nonsignificant increase). M25, 25 months; etc. 
est correlation coefficients. As shown in Figure $6 \mathrm{~A}$, the extent of mtDNA synthesis generally increased during the first months of life. A decrease during old age, i.e., between M25 and M30, was found in all neurons studied; the fact that mitral cells and neurons of pontic nuclei only showed a nonsignificant decrease was due to the fact that these cells could be evaluated only for 3 mice at M30. These results for neurons support Miquel's $(54,55)$ concept of the importance of mitochondria for explaining the phenomenon of aging. It should be added that, surprisingly, most values of 25-month-old mice exceeded those of 20-month-old animals. Since only about $35 \%$ of the initial group reached an age of 25 months, this temporary increase might be due to a selection of the animals; this selection, however, is fully in line with the hypotheses that should be tested,

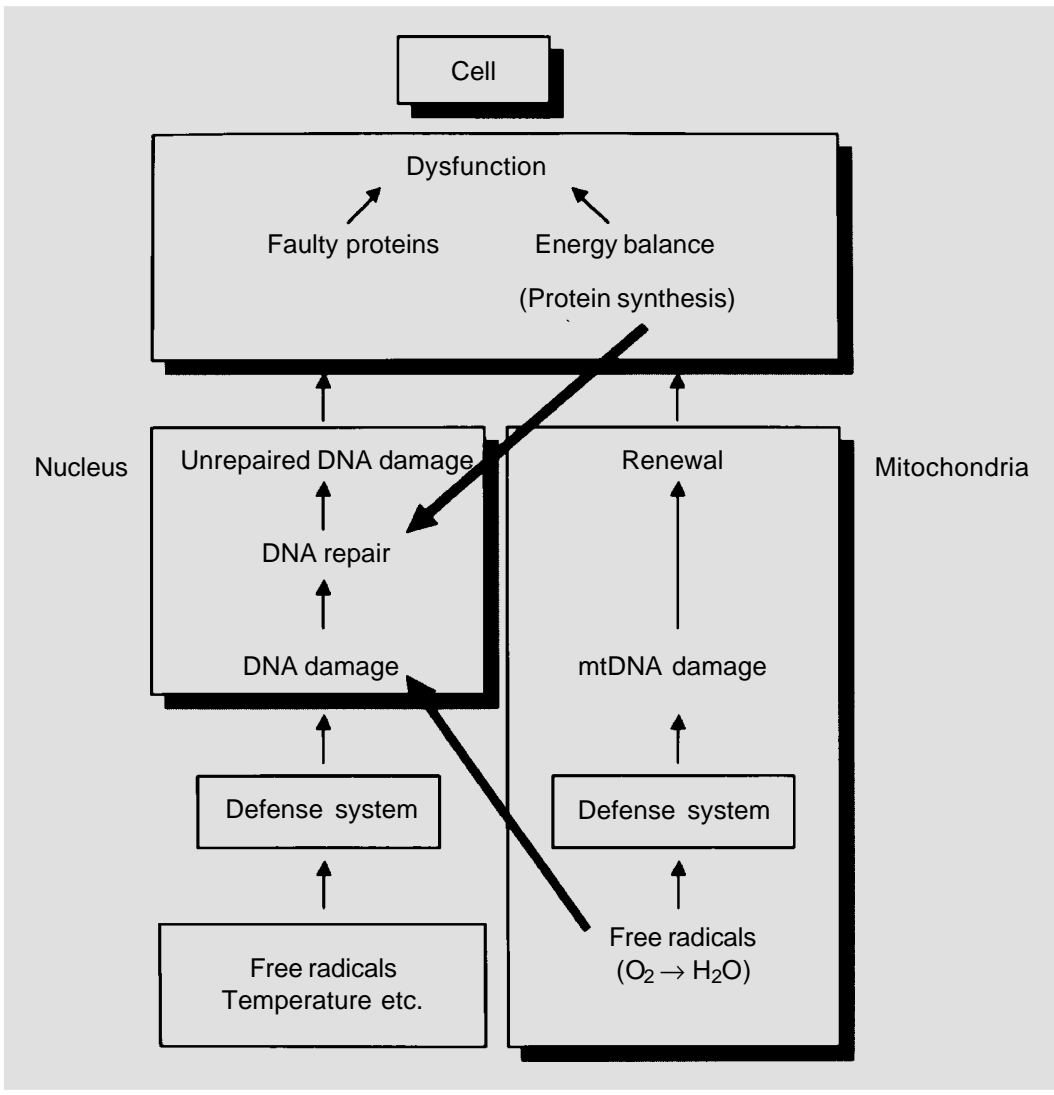

Figure 7 - Scheme of events within the nucleus and mitochondria according to leading hypotheses for explaining the phenomenon of aging. For details, see text. i.e., that aging is associated with a decreased extent of mtDNA synthesis and/or a diminished DNA repair capacity. In contrast to the neurons studied, epithelial cells of the choroid plexus (which are also non-proliferating cells; 24) failed to show an age-related effect.

Figure 6B demonstrates that indeed some cell types show a significant decrease of nUDS during old age, as predicted according to the hypothesis of Gensler and Bernstein (56). It is remarkable that a decrease coinciding with that of mtDNA synthesis was only found for distinct neurons within the cortex and hippocampus; glial and endothelial cells, but also small neurons such as cerebellar granular cells, must be excluded from further discussion, since it is impossible to measure their extent of mtDNA synthesis by light microscopy. Also plexus epithelial cells showed coincidental results, insofar that no age-related effect was detected for mtDNA synthesis or nUDS. Possibly a dysfunction of these cells might be incompatible with life. However, large neurons also exist (Purkinje cells) that show an age-related decline of mtDNA synthesis, but not of nUDS. In addition, no signs of unrepaired DNA damage could be detected within the nDNA of these Purkinje cells of M30 mice, in contrast to cortical pyramidal cells and hippocampal granular and pyramidal cells where remaining unrepaired nDNA damage was indirectly shown (particularly within the heterochromatin; Korr $\mathrm{H}$, unpublished results). The results presented, taken as a whole, indicate that most neurons contain mitochondria with damaged mtDNA during old age; however, in distinct cell types the damage to nDNA will not accumulate with increasing age, possibly due to specific mechanisms, the details of which are unknown up to now (increased DNA repair capacity or increased content of those enzymes which are involved in cellular defense against free radicals).

Figure 7 schematically shows the course of events within the nucleus and mitochon- 
dria according to both hypotheses mentioned above. In addition, some interrelationships (large arrows) are considered according to literature data. Since the defense system against free radicals within the mitochondria becomes more and more insufficient during old age, free radicals lead to additional nDNA damage (for a review, see Ref. 58). Furthermore, a decreased energy production caused by a decreased number of well-working mitochondria will lead to a lower rate of DNA repair, since this latter process is energy dependent. In summary, the results presented in Figure 6 can be explained by this scheme (Figure 7) and thus support both concepts proposed to understand the phenomenon of aging. However, these results do not permit us to decide which of the two hypotheses is dominant. At present, most literature data support the idea initially proposed by Harman (59) that mitochondria play a crucial role in cell senescence.

\section{Acknowledgments}

The authors are indebted to Professor Brigitte Maurer-Schultze, formerly Institut für Med. Strahlenkunde, University of Würzburg, for advice and criticism during the preparation of the manuscript.

\section{References}

1. Attardi G \& Schatz R (1988). Biogenesis of mitochondria. Annual Review of Cell Biology, 4: 289-333.

2. Johns DR (1995). Mitochondrial DNA and disease. New England Journal of Medicine, 333: 638-644.

3. Nass MMK (1969). Mitochondrial DNA: advances, problems and goals. Science, 165: 25-35.

4. Neubert D, Helge H \& Bass R (1965). Einbau von Thymidin in die Desoxyribonucleinsäure von Mitochondrien. NaunynSchmiedeberg's Archiv für Experimentelle Pathologie und Pharmakologie, 252: 258-268.

5. Lonati-Galligani M, Lohmann PHM \& Berends $F$ (1983). The validity of the autoradiographic method for detecting DNA repair synthesis in the rat hepatocytes in primary culture. Mutation Research, 113: 145-160.

6. Avola R, Serra J, Curti D, Lombardo B, Remis M, Condorelli DF \& Giuffrida AM (1986). Nuclear and mitochondrial DNA synthesis and energy metabolism in primary rat glial cell cultures. Neurochemical Research, 11: 789-800.

7. Nussdorfer GG, Mazzocchi G \& Gottardo $G$ (1974). Investigations on turnover of adrenocortical mitochondria. II. Effect of chronic treatment with $\mathrm{ACTH}$ on the ${ }^{3} \mathrm{H}$ thymidine incorporation into rat zona fasciculata mitochondria. Cell and Tissue Research, 151:281-292.
8. Nussdorfer GG, Mazzocchi G, Rebuffat $P$, Belloni AS, Gottardo G \& Gambino AM (1975). Investigations on the turnover of adrenocortical mitochondria. III. Stereologic and autoradiographic observations on the effect of chronic treatment with dexamethasone on the rat zona fasciculata mitochondria. Cell and Tissue Research, 163: 273-290.

9. Nussdorfer GG, Mazzocchi G, Robba C, Belloni A \& Gambino A (1977). Investigations on the turnover of adrenocortical mitochondria. VI. An autoradiographic study of the effect of ACTH on the radioactivity decay in the mitochondrial compartment from the zona fasciculata of ${ }^{3} \mathrm{H}$ thymidine injected rats. Anatomical Record, 188: 125-132.

10. Nussdorfer GG, Neri G \& Mazzocchi $G$ (1978). Investigations on the turnover of adrenocortical mitochondria. XII. Studies on the mechanism of the ACTH-induced elongation of the half-life of rat zona fasciculata mitochondria. Anatomical Record, 192: 435-440.

11. Mazzocchi G, Robba C, Neri G, Gottardo G \& Nussdorfer GG (1976). Investigations on the turnover of adrenocortical mitochondria. V. An autoradiographic study of the radioactivity decay in the mitochondrial compartment from the adrenal cortex of ${ }^{3} \mathrm{H}$-thymidine-injected rats. Cell and Tissue Research, 172: 149-156.

12. Korr H \& Schultze B (1989). Unscheduled DNA synthesis in various types of cells of the mouse brain in vivo. Experimental Brain Research, 74: 573-578.
13. Korr H, Koeser KC, Oldenkott S \& Schmidt $H$ (1989). X-ray dose-effect relationship of unscheduled DNA synthesis and spontaneous unscheduled DNA synthesis in mouse brain cells studied in vivo. Radiation and Environmental Biophysics, 28: 13-26.

14. Reichard P \& Estborn B (1951). Utilization of desoxyribosides in the synthesis of polynucleotides. Journal of Biological Chemistry, 188: 839-846.

15. Schultze B (1969). Autoradiography at the cellular level. In: Pollister AE (Editor), Techniques in Biological Research. Vol. III, Part B. Academic Press, New York, London.

16. Cleaver JE (1967). Thymidine metabolism and cell kinetics. In: Neuberger A \& Tatum EL (Editors), Frontiers of Biology. Vol. 6. North-Holland Publication Company, Amsterdam.

17. Korr H, Kurz C \& Bertram C (1989). Extent of mitochondrial DNA synthesis of different cell types in the brain of the adult mouse. Clinical Neuropathology, 8: 236 (Abstract).

18. Bryant BJ (1966). The incorporation of tritium from thymidine into proteins of the mouse. Journal of Cell Biology, 29: 29-36.

19. Commerford SL, Carsten AL \& Cronkite EP (1977). The distribution of tritium in the glycogen, hemoglobin and chromatin of mice receiving tritium in their drinking water. Radiation Research, 72: 333-342.

20. Korr H \& Schmidt H (1988). An improved procedure for background correction in autoradiography. Histochemistry, 88: 407410. 
21. England JM, Rogers AW \& Miller RG (1973). The identification of labelled structures on autoradiographs. Nature, 242: 612-613.

22. Howard A \& Pelc SR (1951). Nuclear incorporation of P-32 as demonstrated by autoradiographs. Experimental Cell Research, 2: 178-187.

23. Dolbeare F (1995). Bromodeoxyuridine: a diagnostic tool in biology and medicine. Part I: Historical perspectives, histochemical methods and cell kinetics. Histochemical Journal, 27: 339-369.

24. Korr H (1980). Proliferation of different cell types in the brain. Advances in Anatomy, Embryology and Cell Biology, 61: 1-72.

25. Setlow RB \& Carrier WL (1964). The disappearance of thymine dimers from DNA: An error-correcting mechanism. Proceedings of the National Academy of Sciences, USA, 51:226-231.

26. Boyce RP \& Howard-Flanders P (1964). Release of ultraviolet light-induced thymine dimers from DNA in E. coli K-12. Proceedings of the National Academy of Sciences, USA, 51: 293-300.

27. Rasmussen RE \& Painter RB (1964). Evidence for repair of ultraviolet damaged deoxyribonucleic acid in cultured mammalian cells. Nature, 203: 1360-1362.

28. Korr H (1987). Autoradiographische Untersuchungen zum Vergleich der DNASyntheserate proliferierender Zellen zur DNA-Reparatur-Syntheserate nichtproliferierender Zellen im Gehirn der adulten Maus. Verhandlungen der Anatomischen Gesellschaft, 81: 851-852.

29. Painter RB \& Young BR (1972). Repair replication in mammalian cells after $\mathrm{X}$-irradiation. Mutation Research, 14: 225-235.

30. Regan JD \& Setlow RB (1974). Two forms of repair in the DNA of human cells damaged by chemical carcinogens and mutagens. Cancer Research, 34: 3318-3325.

31. Korr H, Bertram C, Voßen U, Schmitz C, Bunzeck S, Nacken M \& Karbach F (1990). The phenomenon of aging. In: Elsner $\mathrm{N} \&$ Roth G (Editors), Brain-Perception-Cognition. 18th Göttingen Neurobiology Conference. Thieme, Stuttgart, New York, 348 (Abstract).

32. Korr H, Philippi V, Helg C, Schiefer J, Graeber MB \& Kreutzberg GW (1997). Unscheduled DNA synthesis and mitochondrial DNA synthetic rate following injury of the facial nerve. Acta Neuropathologica (in press).

33. Yoshizawa K, Furuno I, Yada T \& Matsudaira $\mathrm{H}$ (1978). Induction and repair of strand breaks and 3'-hydroxy terminals in the DNA of mouse brain following gamma irradiation. $\mathrm{Bi}$ ochimica et Biophysica Acta, 521: 144-154.
34. Cerda H, Johanson KJ \& Rosander K (1979). Radiation-induced DNA strand breaks and their repair in the developing rat brain. International Journal of Radiation Biology, 36: 65-73.

35. Cerda H \& Rosander K (1983). DNA damage in irradiated endothelial cells of the rat cerebral cortex. Protective action of cysteamine in vivo. Radiation Research, 95: 317-326.

36. Wheeler KT \& Wierowski JV (1983). DNA accessibility: A determinant of mammalian cell differentiation. Radiation Research, 93: 312-318

37. Wheeler KT \& Wierowski JV (1983). DNA repair kinetics in irradiated undifferentiated and terminally differentiated cells. Radiation and Environmental Biophysics, 22: 3-19.

38. Singh G, Hauswirth WW, Ross WE \& Neims AH (1985). A method for assessing damage to mitochondrial DNA caused by radiation and epichlorohydrin. Molecular Pharmacology, 27: 167-170.

39. Clayton DA, Doda JN \& Friedberg NC (1974). The absence of pyrimidine dimer repair mechanism in mammalian mitochondria. Proceedings of the National Academy of Sciences, USA, 71: 2777-2781.

40. Le Doux SP, Wilson GL, Beecham EZ, Steunser T, Wassermann K \& Bohr VA (1992). Repair of mitochondrial DNA after various types of DNA damage in Chinese hamster ovary cells. Carcinogenesis, 13: 1967-1973.

41. Yakes FM \& van Houten B (1997). Mitochondrial DNA damage is more extensive and persists longer than nuclear DNA damage in human cells following oxidative stress. Proceedings of the National Academy of Sciences, USA, 94: 514-519.

42. Robin ED \& Wong $R$ (1988). Mitochondrial DNA molecules and virtual number of mitochondria per cell in mammalian cells. Journal of Cellular Physiology, 136: 507-513.

43. Satoh M \& Kuroiwa $T$ (1991). Organization of multiple nucleoids and DNA molecules in mitochondria of a human cell. Experimental Cell Research, 196: 137-140.

44. Kuroiwa $T$, Ohta $T$, Kuroiwa $H$ \& Shigeyuki K (1994). Molecular and cellular mechanisms of mitochondrial nuclear division and mitochondriokinesis. Microscopical Research and Techniques, 27: 220-232.

45. Clayton DA (1982). Replication of animal mitochondrial DNA. Cell, 28: 693-705.

46. Ashwell M \& Work TS (1970). The biogenesis of mitochondria. Annual Review of Biochemistry, 39: 251-290.
47. Maurer W \& Primbsch E (1964). Größe der B-Selbstabsorption bei der ${ }^{3} \mathrm{H}$-Autoradiographie. Experimental Cell Research, 33: 8-18.

48. Korr H (1985). Determination of correction factors of ${ }^{3} \mathrm{H}$-B-self-absorption for quantitative evaluation of grain number in autoradiographic studies. Interferometric studies of different cell types in the mouse brain. Histochemistry, 83: 65-70.

49. Korr H, Bauer K, Bunzeck A-S, Nacken M \& Karbach FT (1997). Correction factors of ${ }^{3} \mathrm{H}$-ß-self-absorption for quantitative autoradiography of different cell types in the brain of pre- and postnatal mice. Histochemistry and Cell Biology (in press).

50. Schmitz C (1994). Spontane DNAReparatur-Syntheserate verschiedener Zellarten in Cortex und Hippocampus der Maus als Funktion des Lebensalters. Doctoral thesis, Medizinische Fakultät der RWTH Aachen.

51. Gross NJ, Getz GS \& Rabinowitz M (1969). Apparent turnover of mitochondrial desoxyribonucleic acid and mitochondrial phospholipids in the tissue of the rat. Journal of Biological Chemistry, 244: 1552-1562.

52. Korr H (1981). Light microscopical autoradiography of nervous tissue. In: Heym C \& Forssmann WG (Editors), Techniques in Neuroanatomical Research. Springer Verlag, Berlin, Heidelberg, New York, 218244.

53. Menzies RA \& Gold PH (1971). The turnover of mitochondria in a variety of tissues of young and aged rats. Journal of Biological Chemistry, 246: 2425-2429.

54. Miquel J (1991). An integrated theory of aging as the result of mitochondrial-DNA mutation in differentiated cells. Archives of Gerontology and Geriatrics, 12: 99-117.

55. Miquel J (1992). An update on the mitochondrial DNA mutation hypothesis of cell aging. Mutation Research, 275: 209-216.

56. Gensler HI \& Bernstein H (1981). DNA damage as the primary cause of aging. Quarterly Review of Biology, 56: 279-303.

57. Zurcher C, van Zwieten MJ, Solleveld HA \& Hollander CF (1982). Aging research. In: Forster HL (Editor), The Mouse in Biomedical Research. Vol. IV. Academic Press, New York, 11-35

58. Bandy B \& Davidson AJ (1990). Mitochondrial mutations may increase oxidative stress: implications for carcinogenesis and aging? Free Radical Biology and Medicine, 8: 523-539.

59. Harman D (1972). The biological clock: The mitochondria? Journal of the American Geriatrics Society, 20: 145-147. 